"SME perceptions of the independent review and accounting skills on bank financing: South African perspective"

\begin{tabular}{|c|c|c|}
\hline AUTHORS & \multicolumn{2}{|l|}{$\begin{array}{l}\text { Francois Coetzee } \\
\text { Pieter W. Buys }\end{array}$} \\
\hline ARTICLE INFO & \multicolumn{2}{|c|}{$\begin{array}{l}\text { Francois Coetzee and Pieter W. Buys (2017). SME perceptions of the } \\
\text { independent review and accounting skills on bank financing: South African } \\
\text { perspective. Banks and Bank Systems, 12(2), 51-59. } \\
\text { doi:10.21511/bbs.12(2).2017.05 }\end{array}$} \\
\hline DOI & \multicolumn{2}{|c|}{ http://dx.doi.org/10.21511/bbs.12(2).2017.05 } \\
\hline RELEASED ON & \multicolumn{2}{|l|}{ Friday, 23 June 2017} \\
\hline RECEIVED ON & \multicolumn{2}{|l|}{ Thursday, 13 April 2017} \\
\hline ACCEPTED ON & \multicolumn{2}{|l|}{ Wednesday, 10 May 2017} \\
\hline & \multicolumn{2}{|c|}{$(\mathrm{cc})$ EY-NC } \\
\hline LICENSE & \multicolumn{2}{|c|}{$\begin{array}{l}\text { This work is licensed under a Creative Commons Attribution-NonCommercial } 4.0 \\
\text { International License }\end{array}$} \\
\hline JOURNAL & \multicolumn{2}{|l|}{ "Banks and Bank Systems" } \\
\hline ISSN PRINT & \multicolumn{2}{|l|}{$1816-7403$} \\
\hline ISSN ONLINE & \multicolumn{2}{|l|}{$1991-7074$} \\
\hline PUBLISHER & \multicolumn{2}{|c|}{ LLC "Consulting Publishing Company "Business Perspectives" } \\
\hline FOUNDER & \multicolumn{2}{|c|}{ LLC "Consulting Publishing Company "Business Perspectives" } \\
\hline & & ニシ: \\
\hline NUMBER OF REFERENCES & NUMBER OF FIGURES & NUMBER OF TABLES \\
\hline 46 & 7 & 2 \\
\hline
\end{tabular}

(C) The author(s) 2023. This publication is an open access article. 


\title{
SME perceptions of the independent review and accounting skills on bank financing: South African perspective
}

\begin{abstract}
Access to bank financing is regularly rated as one of the biggest obstacles to SME sustainability. With the introduction of the independent review as an alternative to the statutory audit, banks may have inevitably lost their risk assessment reassurance that audits provided. Previous research found that banks have adjusted to this situation by no longer insisting on audited financial statements. The research undertaken in this study aims to, firstly, investigate SME owner/managers' perceptions about what banks require when assessing bank loan applications; and, secondly, to gauge SME owner/manager's attitudes towards the value they perceive accounting may contribute to their sustainability. It was found from an SME perspective, that although an independent review is the current way to go, many SME owner/managers consider their own accounting skills, as the language of business, to be lacking. This could potentially have repercussions in inadvertently promoting further asymmetric financial information, and thereby limiting successes in obtaining finance.
\end{abstract}

Keywords: accounting proficiency, audit, bank financing, independent review, SME sustainability.

JEL Classification: M13, M41, M42, M48.

Received on: $13^{\text {th }}$ of April, 2017.

Accepted on: $10^{\text {th }}$ of May, 2017.

\section{Introduction}

Ask any business owner why he/she is in business, and you are likely to hear a hearty rendition of "Money makes the world go round", as in the Broadway musical Cabaret (Kander, 1965). For many small and medium enterprises (SMEs) around the world, no words ring more true. The plight of SMEs globally to attain and achieve sustainability is a much-explored topic and is often regarded as the entrepreneurial domain of the world economy (GEM, 2014). However, to make their world go around, SMEs do need money (as per the Kander reference above). This need is corroborated by Ayyagari et al. (2012) and Beck et al. (2005) who all consider SMEs' sustainability to be unequivocally concomitant to their ability to access adequate finance. Mills and McCarthy (2014) are of the opinion that bank loans have traditionally been important to SMEs. Unfortunately, banks have also historically regarded SMEs as potentially high-risk clients (Haynes et al., 1999), and historically would have been subjected to a rigorous risk assessment process. This process, more often than not, led to banks requiring audited financial statements from SMEs (SAICA, 2010).

A problematic situation arose in the contemporary South African business environment, with the advent of the new Companies Act, No. 71 of 2008

\footnotetext{
(c) Francois Coetzee, Pieter W. Buys, 2017.

Francois Coetzee, Ph.D. Candidate, NWU School of Business and Governance, North-West University, Potchefstroom, South Africa. Pieter W. Buys, Professor, WorkWell Research Unit and NWU School of Business and Governance, North-West University, Potchefstroom, South Africa.
}

This is an Open Access article, distributed under the terms of the Creative Commons Attribution-NonCommercial 4.0 International license, which permits re-use, distribution, and reproduction, provided the materials aren't used for commercial purposes and the original work is properly cited. (hereafter the Act). Before the implementation of the new Act, SMEs (trading in a company format) had no option but to undergo an annual statutory audit. With the abolishment of the statutory audit requirement for qualifying entities, audited financial statements are no longer required. As such, a new era has seen the light in South Africa, which effectively allows qualifying entities to choose between either i) an independent review or ii) a conventional audit. Griffin (2014) explains that an audit is done in accordance with generally accepted auditing standards, whereas an independent review is done in terms of the standards for accounting and review engagements. As such, the objective of an audit is to offer reasonable assurance that the financial statements as a whole are fairly presented. An independent review does not attempt to offer such an assurance, but only offers a limited assurance that no material issues were identified during the review procedures undertaken. The concern is, therefore, whether the SME that chooses not to follow the conventional audit route may run into problems when trying to access bank finance, since banks may not be keen to base their risk assessments on a limited assurance rather than a reasonable assurance.

Building on the above, according to Fatoki and Garwe (2010), the inaccessibility of finance opportunities is second only to (accounting) education and training when evaluating the reasons for low SME sustainability. Rajaram (2008) concurs and found that the lack of accounting skills is a contributing factor to the poor performance of SMEs in South Africa, and he postulates that possessing a basic accounting skill set may augment sustainability and profitability within the SME sector, to the extent that access to financing may become less arduous. 


\section{Literature review}

1.1. Perspectives on small and medium enterprises. 1.1.1. Background. Different economies and institutions have different perspectives of the business characteristics applicable to an SME. Typically, however, Malhotra et al. (2007) refer to SMEs as independent business entities that have an owner/manager structure, while Mahembe (2011) also brings the number of employees and financial size aspects into the equation. In a South African survey by FinMark (2010), SMEs were defined as privately-held business entities that, among others, employ fewer than 200 employees and have a turnover of less than ZAR50 million ${ }^{1}$. For the purpose of this paper, therefore, SMEs are defined as business entities that fall within the criteria of the FinMark definition.

SMEs are globally considered to be important economic contributors that play an important role in terms of job creation and stimulating economic growth (The Business Place, 2009). SMEs, locally in South Africa and internationally, seem to have a positive pattern of involvement in economies, as is illustrated in the table below.

Table 1. SME economic relevance

\begin{tabular}{|l|c|c|}
\hline \multicolumn{1}{|c|}{ Country } & $\begin{array}{c}\text { GDP } \\
\text { contribution }\end{array}$ & $\begin{array}{c}\text { Employment creation as } \\
\% \text { of domestic workforce }\end{array}$ \\
\hline Japan (Robu, 2013) & $60 \%$ & $69 \%$ \\
\hline European Union (Robu, 2013) & $52 \%$ & $66 \%$ \\
\hline United Kingdom (FSB, 2016) & $47 \%$ & $60 \%$ \\
\hline Canada (Industry Canada, 2013) & $41 \%$ & $70 \%$ \\
\hline USA (Robu, 2013) & $65 \%$ & $58 \%$ \\
\hline South Africa (Abor and Quartey, 2010) & $57 \%$ & $61 \%$ \\
\hline
\end{tabular}

Seen in light of the above, a thriving SME economic sector should inadvertently contribute tremendously to a thriving local economy, which, in turn, should positively affect society in general. It is, therefore, of vital importance that SMEs be equipped and empowered as proficiently and expediently as possible.

1.1.2. The importance of bank finance. As far back as 2004, Nieuwenhuizen and Groenewald (2004) claimed that the main obstacle to South African SME sustainability was accessing bank financing. What makes this even more significant is that these claims were made before the credit crunch of 2008. According to the European Union (2013), the current economic environment has brought the plight of the SME, concerning ever tightening credit accessibility, to the forefront again.

${ }^{1}$ ZAR being South African rand and the local currency. At the time of writing, the exchange rate was approximately U $\$ 1=$ ZAR13.60.
The NFIB (2012) reported that more than $85 \%$ of SMEs used bank finance in one form or another. Furthermore, according to the European Union (2013) and the Office of Advocacy (2014), SME bank financing is used for various reasons, including i) as start-up business financing, ii) working capital purposes such as inventory acquisition and cash position strengthening, and iii) expanding business operations inclusive of property, plant and equipment acquisitions. The European Commission, in collaboration with the European Central Bank, conducted research on the access to finance of SMEs in the European Union (European Commission, 2008) and published the following:

- Access to finance was the second biggest obstacle experienced by SMEs, after finding customers.

- Banks were the most frequently used source of external financing.

- Bank loans comprised $85 \%$ of all loans issued during the period of the research.

- Bank finance was typically in the form of overdrafts, equipment financing and bank loans.

- SME owner/managers considered financing from banks as difficult to access.

- Approximately one third of SMEs did not receive the financing they had planned for.

From a more locally South African perspective, research conducted by Mazanai and Fatoki (2012), Mahembe (2011) and Turner et al. (2008) found that South African SMEs considered access to financing as a significant obstacle to the sustainability of their businesses, and that only between 25 and $30 \%$ of bank finance applications are eventually successful.

A reason why SME accessibility to funding has become such a conundrum seems to have become a matter of perception. On the one hand, the bankers are adamant that SMEs and regulators are to blame for the funding problems being experienced, while, on the other hand, the SMEs blame i) banks for unachievable collateral requirements and ii) regulators for effectively forcing banks to make loans more difficult to get (Wiersch and Shane, 2013). This is echoed by Wignaraja and Jinjarak (2015) who approximate that $60 \%$ of SMEs worldwide are financially inhibited by funding constraints and Dalberg (2014) who estimates that $75 \%$ of new SMEs that apply for bank finance are rejected.

With banks being more risk averse since the 2008 financial crisis, assessing the creditworthiness of SMEs has become even more important. This is, however, no mean feat, as information asymmetry becomes an ever-increasing obstacle. Many SMEs have inadequate financial systems allowing banks no transparency as to the true financial position of 
the business (Mills and McCarthy, 2014). Whether one likes to admit it or not, the fact that banks are confronted with extensive banking regulations and statutory oversight is not by their own choice. Taking the above findings slightly further, Nieman and Neuwenhuizen (2009) found that start-up SMEs fail within the first two years due to i) the inaccessibility to bank funding, and ii) cashflow problems attributable to a lack of financial management skills. More recent research by Turton and Herrington (2012) confirms this when they found that the two main contributing factors to the poor performance of SMEs in South Africa are i) accessibility to funding and ii) poor management skills.

1.1.3. The accounting conundrum. Kesseven (2012) raises the point that there are both external and internal factors that may contribute to SME sustainability. Although external factors are typically uncontrollable by the SME, they may have more control over internal factors such as organizational, management and financial abilities, which, in turn, may directly contribute to an SMEs' ability to convince banks of their sustainability.

Some of the world's most renowned and successful businessmen and entrepreneurs acknowledge that they regard accounting methodologies and principles as key contributors to their success, as illustrated by the following quotes:

"Obviously, you have to know accounting. It's the language of practical business life..." (Munger, 1994).

"You have to understand accounting and you have to understand the nuances of accounting. It's the language of business..." (Buffet and Clark, 2008).

Why does the metaphor of accounting being the language of business hold such significance? Bloomberg and Noyes (2008) explain by drawing a very insightful parallel between accounting and language:

"People communicate through written natural languages by selecting words from a standard vocabulary, combining them in meaningful ways ..."

"People communicate through accounting reports by selecting accounts from a standard vocabulary, combining them in meaningful ways ..."

Keeping the above in mind, accounting therefore needs to be able to, in a meaningful manner, communicate aspects that factually portray the economic realities of the business entity. Nevertheless, Haron et al. (2013), as well Sian and Roberts (2009), found that SME owner/managers seldom have any formal training in accounting and are subsequently often perplexed by the complexity of accounting reports. This lack of knowledge concerning the basic principles and nuances of accounting mostly translates into a misguided notion that accounting has no value to add. Because the SME lacks accounting knowledge, it is often disregarded in the business. It is this combination of inadequate accounting communication skills, which, according to Chimucheka and Rungani (2011), exacerbates the sustainability challenges already facing SMEs.

SMEs, however, are dependent on bank financing, and banks, in turn, rely heavily on financial information in their lending evaluation process. With banks already reluctant to take risks in the SME financing space, providing asymmetric information will not aid the cause. Various research projects conducted by Haron et al. (2013), Amidu et al. (2011) and Osuala (2009) support assertions that some level of accounting sophistication can provide a level of mitigation in convincing finance providers of management savvy present within the entity and, therefore, can also reduce risk levels specific to such an entity. We can consequently infer that an SME's probability of accessing bank financing will increase, if management has a better understanding of accounting principles and its value added to the business itself.

\section{Research objectives and method}

When assessing a loan application, banks will undoubtedly require some kind of financial statement from the SME in order to evaluate potential associated risks. Unless the SME can provide such financial statements, banks may mitigate their risk by either rejecting the application or by tightening the terms of the loan agreement (Dalberg, 2014). With audited SME financial statements potentially no longer required when applying for bank finance, the question becomes what SMEs can do to negate the banks' high-risk perception. Therefore, in order to empower SMEs, this article will, as its first research problem, investigate whether SME managers/owners agree with the premise of the Act that audited financial statements no longer hold any advantage to SMEs in applying for bank finance. Furthermore, as a related second research problem, the article will also consider the perception of SME manager/owners as to their own accounting prowess in their battle for sustainability.

An empirical survey investigates the two objectives in mind, namely i) the experiences and attitudes of SME owner/managers regarding the necessity of audited financial statements in obtaining bank finance, and ii) the SME owners/managers' perception of their own accounting skill set and the value of accounting knowledge within their own contexts. Finally, some concluding remarks will also be provided. 
In terms of the research approach used, this study is based on a tabulated questionnaire completed during interviews with the manager/owners of participating SMEs, in which section 1 was in a Likert 5 point, strongly agree-strongly disagree format, while section 2 was an in-depth personal interview format. The format and questions of the Likert scale and questionnaires were drawn from similar surveys that were previously conducted during SME access to finance research (European Union, 2013; Ackah and Vuvor, 2011; European Commission, 2009; Mutezo, 2005). The questionnaires were slightly adapted to better target and analyze topics pertinent to this study.

To undertake the empirical study, a qualitative research approach, using convenience sampling, has been employed. Convenience sampling is considered an appropriate approach when a targeted, identifiable population is available, and when time, resources and respondent availability are potential issues in the sampling and interview process (Baumberg, 2012). Both Adler and Adler (2012) and Warren (2002) are of the opinion that a (interview-based) qualitative sample size should be approximately 30 interviewees. Baumberg (2012) and Brannen (2012), however, argue that more interviews are necessary and suggest that there should be approximately 40 interviews. Ragin (2012) again is of the opinion that a more appropriate number of interviews is 50 , whereas Gerson and Horowitz (2002) consider 60 interviews to be adequate to draw convincing conclusions. In this specific study, therefore, the SME database of a (registered) external auditing firm with a national footprint was used as the targeted population from which the sample was drawn. A sample of 60 participants from various parts in South Africa and from various industries was selected. The only common denominator is that all participants are considered SMEs per the applied SME definition (see below).
Before taking a closer look at the research results of this study, it is important to be cognisant of the fact that these results are based on perceptions. The information gleaned from the SME owner/managers has not been tested with concrete empirical, right-or-wrong test criteria. Instead, the information is based on what the SMEs perceived their experiences to be. For example, when asked what their perceived knowledge of accounting was, the answers were recorded as what they believed the reality to be. A test was not administered to prove their perceptions right or wrong. To ensure the reliability of the questionnaires, Cronbach's alpha was calculated. The questionnaires testing for the first objective had a Cronbach's alpha of 0.754 , and as this is higher than 0.7 , the questionnaire was accepted as reliable. The questionnaires testing for the second objective had a Cronbach's alpha of 0.742 , and as this is also higher than 0.7 , the questionnaire was also accepted as reliable.

\section{Empirical results}

As indicated earlier, the first objective of this analysis is to examine the extent to which SME manager/owners agree with the supposition that audited financial statements are not essential in obtaining bank finance anymore. With the everincreasing sophistication of accounting requirements for financial statements, the second objective focusses on the views of the SME manager/owners regarding their own accounting skill sets and their perceived value of accounting to their business.

Firstly, in terms of demographics, Figure 1 below indicates the geographic distribution of the participants across the South African provinces, while Figure 2 indicates the spread of participants as per their industry sector.

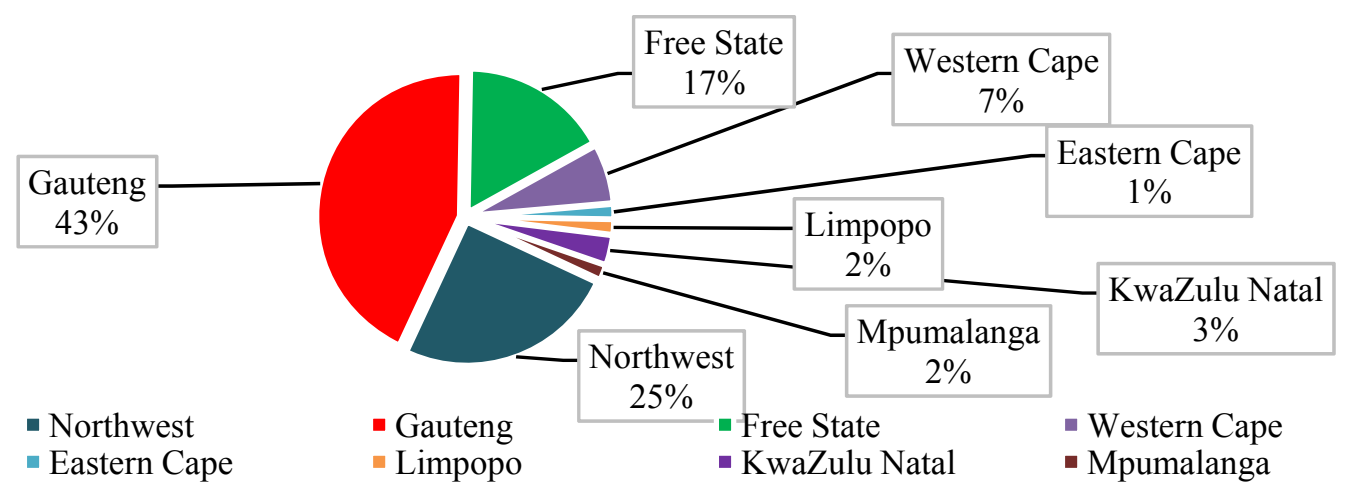

Fig. 1. Participant geographic demographics 


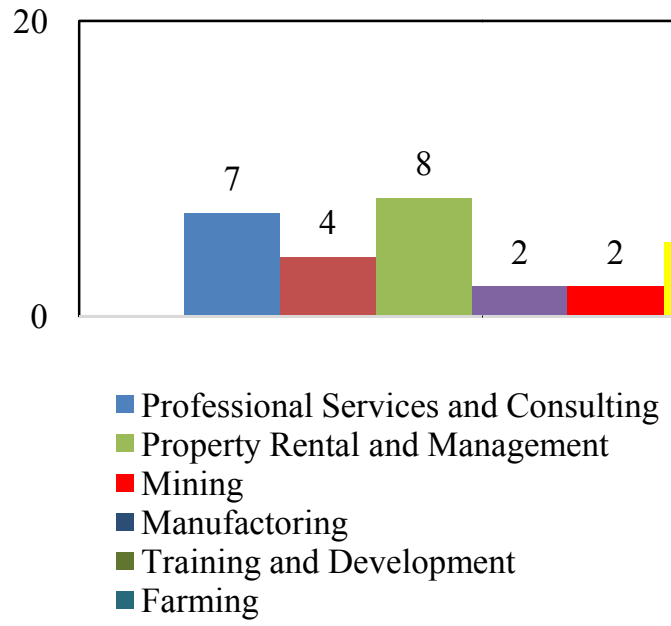

Fig. 2. Participant industry demographics

It can therefore be seen that the participants are spread widely across both the country and diverse industries. The common denominator between the participants is only the fact that they are all SMEs. Secondly, in terms of the detailed requirements pertinent to this study, the questionnaires were structured in such a manner to glean the following pertinent information:

\section{What types of finance are used?}

The figure below indicates the most commonly used types of finance that SMEs rely on.

The research found that overdrafts $(95 \%)$ and property, plant and equipment (or asset) finance $(68.33 \%)$ are the most commonly used financing structures. Other financing options $(5 \%)$ included bank guarantees issued on behalf of SMEs.

What information do the banks require when applying for finance?

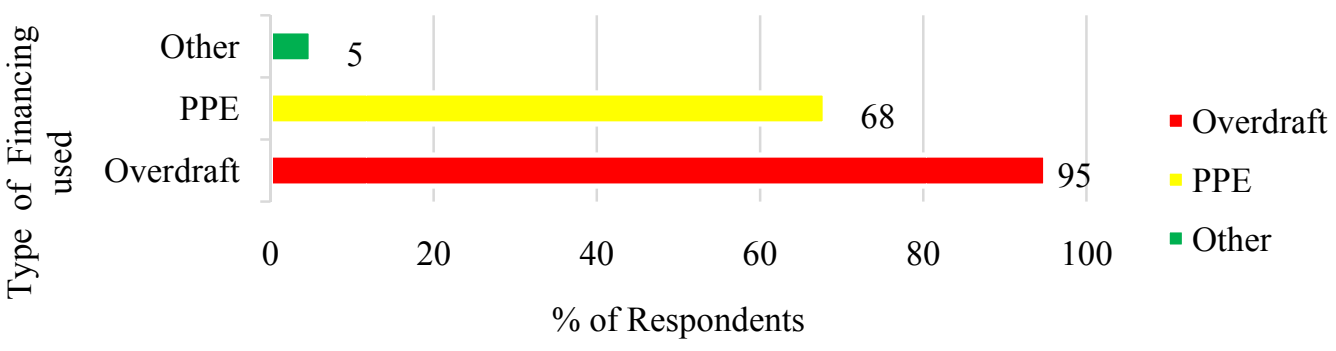

Fig. 3. Popularity of financing options

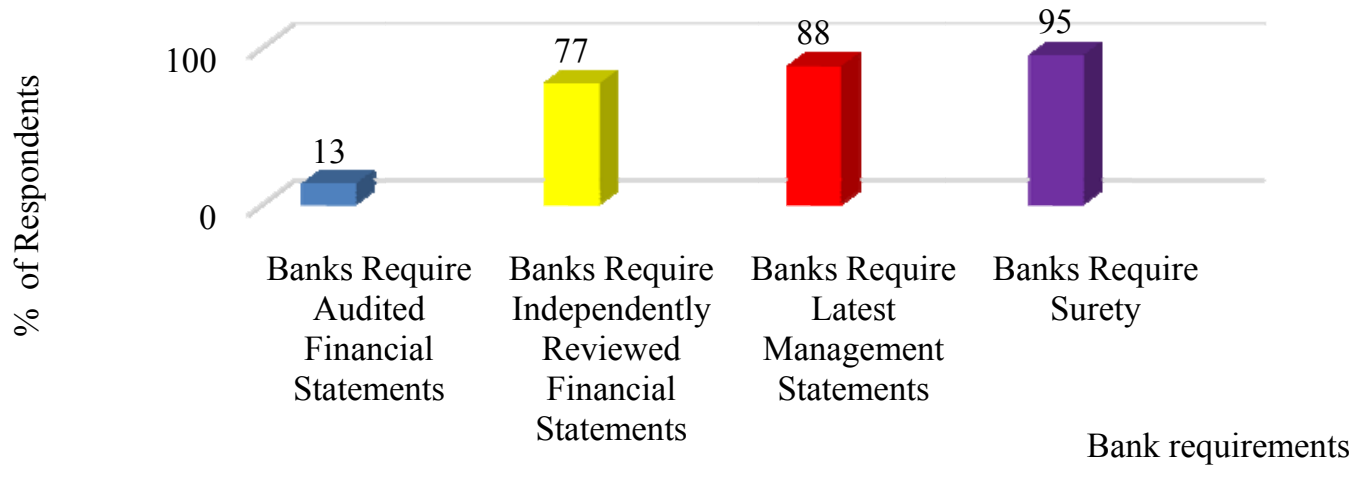

Fig. 4. Information requirements

These results corroborate the premise of the Act in that audited (historical) financial statements are of lesser importance in gauging SMEs' future sustainability and South African banks (should) no longer insist on audited financial statements when assessing SME bank loan applications. Only 13\% of participants were of the opinion that banks still require audited financial statements from them. These participants, however, are entities (e.g., financial services) that are required by the Act to have audits done due to their public interest scores. Their opinion of needing audited financial statements may, thus, have been tainted, as they have 
to supply audited financial statements by default due to other legal requirements, rather than due to a specific request from the bank. Furthermore, 77\% of participants were of the opinion that independently reviewed financial statements were sufficient, while interestingly, as much as $88 \%$ of participants perceived current management statements of importance, and 95\% of participants perceived that availability of surety was regarded as important.

\section{What are the SMEs' perceptions of their under- standing of basic accounting principles?}

The figure below shows the perceptions of SME owner/managers as to their accounting skill sets.

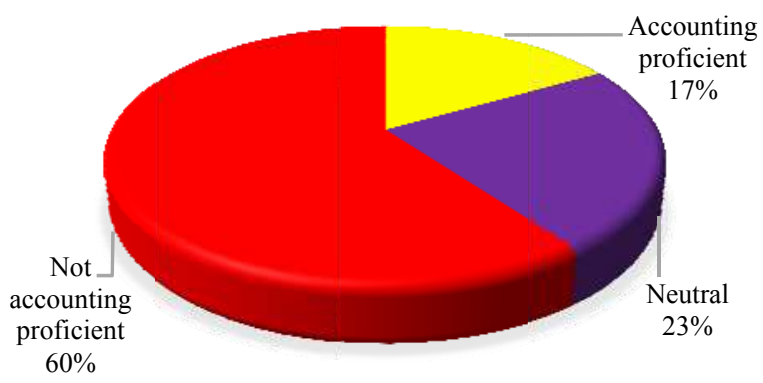

Fig. 5. Perceptions on accounting efficiency

The research found that only $17 \%$ of SME owner/managers were confident that they had adequate knowledge of accounting principles. The research further found that $60 \%$ of managers were of the opinion that they had little to no understanding of basic accounting principles, with $23 \%$ being unsure of their basic accounting knowledge. It would be reasonable to assume that those SMEs that were unsure of their accounting proficiency were a closer correlation to those admitting to a lack of accounting proficiency than to those SMEs that were confident of their accounting proficiency. For the sake of argument, therefore, this means that a large majority of SME owner/managers are of the opinion that they are not proficient in the understanding of basic accounting principles.

\section{What are the SMEs' views on the importance of accounting?}

In terms of perceived importance, the figure below presents the following findings.

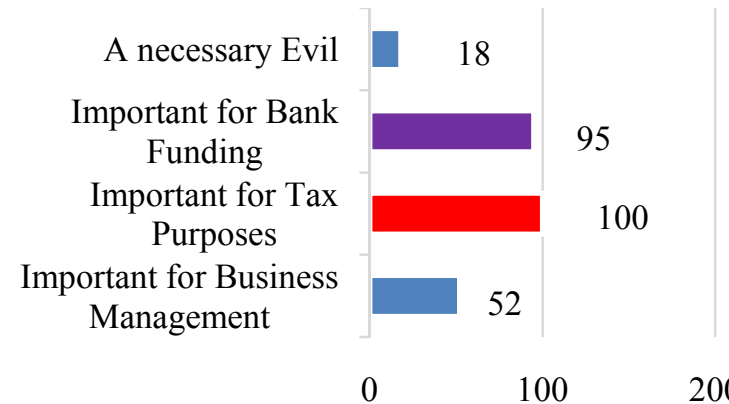

Fig. 6. Perceptions on the importance of accounting
Although managers admitted that they lack basic accounting skills, and would have preferred having an adequate accounting skill set, only $52 \%$ actually envisaged using accounting more constructively in their day-to-day operations. The majority of managers regard accounting as a tool to adhere to statutory tax requirements $(100 \%)$ and as a requirement when bank financing is required (95\%).

\section{Do SMEs believe accounting is beneficial to their sustainability efforts?}

In terms of the perceived contribution accounting makes to SME sustainability, the figure below presents the following findings.

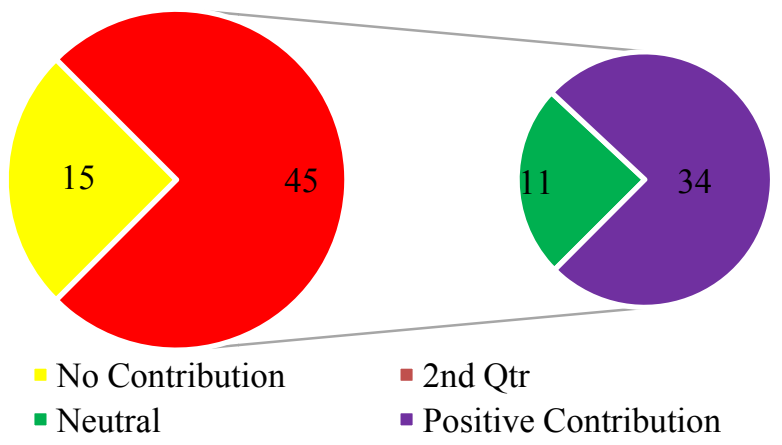

Fig. 7. Perceptions on accounting contribution to sustainability

The research found that out of 60 participants, 15 (25\%) felt accounting had no contribution to make. Of the remaining 45 participants, as much as 34 (56.7\%) were positive about the value that accounting could add to their sustainability, while $11(18.3 \%)$ were neutral in their view concerning the attributable value of accounting. If viewed as SMEs that are either negative or not negative towards accounting, one finds that $75 \%$ of SMEs are not negative towards the potential inputs accounting may have in their business and subsequent sustainability. This corresponds with research done by Chimucheka and Rungani (2011) among SMMEs in East London, South Africa, who found that $73 \%$ of participants were of the opinion that a lack of financial management skills was a threat to their sustainability.

\section{Correlations gleaned from the research}

Spearman's rho correlations were extrapolated from the data gathered from the questionnaires. According to Cohen (1988), correlations, positive or negative, that are between 0.10 and 0.29 , indicate a small effect. Correlations from 0.30 to 0.49 indicate a medium effect and correlations from 0.50 and up indicate a large effect. Although various correlations with low, medium and large statistically significant effects were calculated, only a few with more relevant and statistically larger effects will be discussed further. The following Spearman's rho correlations are especially pertinent: 
Table 2. Spearman's rho correlations

\begin{tabular}{|c|c|c|c|c|}
\hline Spearman's rho & & $\begin{array}{l}\text { Understanding } \\
\text { accounting }\end{array}$ & $\begin{array}{c}\text { Importance of } \\
\text { accounting }\end{array}$ & $\begin{array}{l}\text { Accounting is a } \\
\text { necessary evil }\end{array}$ \\
\hline $\begin{array}{l}\text { Understanding } \\
\text { accounting }\end{array}$ & $\begin{array}{l}\text { Correlation } \\
\text { coefficient } \\
\text { Sig. (2-tailed) } \\
\mathrm{N}\end{array}$ & $\begin{array}{c}1.000 \\
60\end{array}$ & & \\
\hline $\begin{array}{l}\text { Importance of } \\
\text { accounting }\end{array}$ & $\begin{array}{l}\text { Correlation } \\
\text { coefficient } \\
\text { Sig. (2-tailed) } \\
\mathrm{N}\end{array}$ & $\begin{array}{c}.545^{* *} \\
.000 \\
60\end{array}$ & $\begin{array}{c}1.000 \\
60\end{array}$ & \\
\hline $\begin{array}{l}\text { Accounting is a } \\
\text { necessary evil }\end{array}$ & $\begin{array}{l}\text { Correlation } \\
\text { coefficient } \\
\text { Sig. (2-tailed) } \\
\mathrm{N}\end{array}$ & $\begin{array}{c}-.447^{\star *} \\
.000 \\
60\end{array}$ & $\begin{array}{c}-.595^{\star *} \\
.000 \\
60\end{array}$ & $\begin{array}{c}1.000 \\
60\end{array}$ \\
\hline $\begin{array}{l}\text { Accounting is } \\
\text { valuable for } \\
\text { management } \\
\text { purposes }\end{array}$ & $\begin{array}{l}\text { Correlation } \\
\text { coefficient } \\
\text { Sig. (2-tailed) } \\
\mathrm{N}\end{array}$ & $\begin{array}{c}.547^{* *} \\
.000 \\
60\end{array}$ & $\begin{array}{c}.804^{* *} \\
.000 \\
60\end{array}$ & $\begin{array}{c}-.490^{\star *} \\
.000 \\
60\end{array}$ \\
\hline
\end{tabular}

**. Correlation is significant at the 0.01 level (2-tailed).

*. Correlation is significant at the 0.05 level (2-tailed).

The table above indicates the following:

- SME owner/managers who have a basic understanding of accounting are also convinced of the importance of accounting to their business sustainability ( $r=0.545$; large effect).

- SME owner/managers who have a basic understanding of accounting are also convinced that accounting can play an important management role in their business ( $r=0.547$; large effect).

- SME owner/managers who do not understand accounting have a negative correlation to the view on the importance of accounting and think that accounting is nothing more than a necessary evil $(r=-0.447)$; they also do not believe accounting is important for business sustainability $(r=-0.595$; large effect) or that accounting can contribute to business management $(r=-0.490$; medium effect).

- Those SME owners who understand the importance of accounting also believe that accounting can have a valuable contribution as a management tool $(r=0.804$; large effect).

\section{Conclusion}

The literature study undertaken brought to the forefront the dilemma the new Act has created for South African SMEs between choosing an expensive audit or a cheaper independent review alternative, perhaps at the peril of sacrificing a bank's goodwill. The purpose of this research was to investigate whether the local SMEs have embraced the independent review, and whether they consider accounting knowledge and skills to be potentially conducive in their sustainability quests. After closer analysis of the research data, we can draw various conclusions pertaining to the research problems, including:

- From a South African point of view, audits for SMEs seem to have made the extinction list and SMEs may actually prefer the independent review route, because it is more cost effective and has less of an administrative burden.

- The research further confirms that many South African SME owners/managers do not regard themselves as accounting literate and that they regard themselves as being on the lower end of the scale of knowledge of basic accounting principles.

- The research further confirms that South African SME owner/managers are divided on the value accounting can offer their business; with $52 \%$ seeing the daily operational value of accounting to their business and only $18 \%$ seeing no value whatsoever. If one considers that $83 \%$ of owner/managers perceived that they did not have sufficient knowledge of accounting, one may infer that, although $52 \%$ would have liked to use accounting in their business, they cannot and therefore will not, because they simply lack the necessary accounting insights.

The research brings some insight into the muchspeculated topic of the value of audited financial statements to SMEs in terms of the loan application processes. What the research has also brought to light is that SMEs do not have to be cannon fodder when applying for loans. By augmenting their business environment with basic accounting skills, they can potentially improve their chances of favorable loan applications while simultaneously increasing their chances at sustainability. It was earlier indicated that SMEs are a very important part of global economic progress. There is no doubt that SMEs face many challenges on a dayto-day basis, and that we should regard the acumen SMEs demonstrate year in and year out with high regard. However, there are areas of business where SMEs need to step up and show their resilience. They need to consider improving their accounting skill sets. They need to learn the language of business.

In terms of limitations and future research arising from this research, one could include the evaluation of whether an improvement in accounting skill sets will i) improve the loan approval rate of SMEs and ii) improve the sustainability of SMEs. Further research may also be required as to what basic accounting skills are necessary to constitute being proficient in accounting in terms of SME sustainability requirements. 


\section{References}

1. Abor, J., and Quartey, P. (2010). Issues in SME Development in Ghana and South Africa. International Research Journal of Finance and Economics, 39, 218. Retrieved from http://www.eurojournals.com/finance.htm

2. Adler, P. A., and Adler, P. (2012). How many qualitative interviews is enough? Expert voices and early career reflections on sampling and cases in qualitative research. National Centre for Research Methods. Retrieved from http://eprints.ncrm.ac.uk/2273/4/how_many_interviews.pdf

3. Ackah, J., and Vuyor, S. (2011). The Challenges faced by Small \& Medium Enterprises (SMEs) in Obtaining Credit in Ghana. Retrieved from https://www.diva-portal.org/smash/get/diva2:829684/FULLTEXT01.pdf

4. Ayyagari, M., Demirgüç-Kunt, A., and Maksimovic, V. (2012). Financing of Firms in Developing Countries Lessons from Research. World Bank Working Paper.

5. Baumberg, B. (2012). How many qualitative interviews is enough? Expert voices and early career reflections on sampling and cases in qualitative research. National Centre for Research Methods. Retrieved from http://eprints.ncrm.ac.uk/2273/4/how_many_interviews.pdf

6. Beck, T., Demirgüç-Kunt, A., and Maksimovic, V. (2005). Financial and legal constraints to growth: Does firm size matter? The Journal of Finance, 60(1), 137-177.

7. Brannen, J. (2012). How many qualitative interviews is enough? Expert voices and early career reflections on sampling and cases in qualitative research. National Centre for Research Methods. Retrieved from http://eprints.ncrm.ac.uk/2273/4/how_many_interviews.pdf

8. Buffet, M., and Clark, D. (2008). Warren Buffett and the Interpretation of Financial Statements, The search for the Company with a Durable Competitive Advantage. New York: Scriber.

9. Chimucheka, T., and Rungani, E. C. (2011). The impact of inaccessibility to bank finance and lack of financial management knowledge to small, medium and micro enterprises in Buffalo City Municipality, South Africa. African Journal of Business Management, 5(14), 5509-5517.

10. Cohen, J. (1988). Statistical power analysis for the behavioural sciences (Rev. ed.), Orlando, FL: Academic Press.

11. Dalberg. (2014). The Small and Medium Enterprise (SME) Sector: Catalyst for Growth in South Africa. Retrieved from http://www.catalystforgrowth.org/wp-content/uploads/2014/02/JPM_Dalberg_SME-Catalyst-for-Growth.pdf

12. European Commission. (2008). Enterprise and Industry Directorate-General. Final Report of the Expert Group: Accounting System for small enterprises - Recommendations and good Practices.

13. European Commission. (2009). European Central Bank Survey on the access to finance of SMEs. Retrieved from https://www.ecb.europa.eu/stats/pdf/surveys/sme/SME_survey_Questionnaire_publication1.pdf?da270789616ad7c $9 \mathrm{~b} 33 \mathrm{c} 994 \mathrm{~d} 0 \mathrm{bae} 2124$

14. European Union. (2013). Directorate-General for Enterprise and Industry of the European Commission. SMEs' Access to Finance Survey: Analytical Report. Luxembourg: Office for the Official Publications of the European Communities.

15. Fatoki, O., and Garwe, D. (2010). Obstacles to the growth of new SMEs in South Africa: A principal component analysis approach. African Journal of Business Management, 4(5), 729-738.

16. Finmark. (2010). FinScope South Africa Small Business Survey. Retrieved from http://www.finmarktrust.org.za/pages/Focus-Areas/Small,-Micro-and-MediumEnterprises.aspx?randomID=b2697f82-2112-499c-bde5-21944c67abae\&link Path=8\&lID=8_11

17. FSB. (2016). UK Small Business Statistics. Retrieved from http://www.fsb.org.uk/media-centre/small-business-statistics

18. Gerson, K., and Horowitz, R. (2002). Observation and Interviewing: Options and Choices. Qualitative Research in Action. London: Sage.

19. Global Entrepreneurship Monitor. (2014). An alarmingly low level of entrepreneurial activity in spite of high unemployment. Retrieved from http://www.gemconsortium.org /country-profile/108

20. Haron, H., Said, S. B., Jayaraman, K., and Ismail, I. (2013). Factors Influencing Small Medium Enterprises (SMES) in Obtaining Loans. International Journal of Business and Social Science, 4(15), [Special Issue - November 2013]

21. Haynes, G. W., Ou, C., and Berney, R. (1999). Small business borrowing from large and small banks. Business Access to Capital and Credit, 287-327.

22. Industry Canada. (2013). Key small business statistics. Retrieved from https://www.ic.gc.ca/eic/site/061.nsf/vwapj/KSBS-PSRPE_July-Juillet2012_eng.pdf/\$FILE/KSBS-PSRPE_JulyJuillet2012_eng.pdf

23. Kander, J. (1965). Cabaret: The Money Song. Retrieved from https://genius.com/John-kander-money-song-lyrics

24. Kesseven, P. (2012). Why SMEs Ignore Formal Accounting Systems? - Entity Concept Explanation. International Conference on Applied and Management Sciences (IAMS'2012) June 16-17, Bangkok.

25. Mahembe, E. (2011). Literature review on small and medium enterprises' access to credit and support in South Africa. Retrieved from http://www.ncr.org.za/pdfs/Literature\%20Review\%20on\%20SME\%20Access \%20to\%20Credit\%20in\%20South\%20Africa_Final\%20Report_NCR_Dec\%202011.pdf

26. Mazanai, M., and Fatoki, O. (2012). Access to finance in the SME Sector: A South African perspective. Asian Journal of Business Management, 4(1), 58-67.

27. Mazaroll, T. (2012). Financing the small business sector: What has been the impact of GFC? Retrieved on January 16, 2016 from http://theconversation.com/financing-the-small-business-sector-what-has-been-the-impact-of-the-gfc-6894 
28. Munger, C. (1994). A Lesson on Elementary, Worldly Wisdom As It Relates To Investment Management and Business. Retrieved from http://www.ritholtz.com/blog/2012/02/a-lesson-on-elementary-worldly-wisdom-as-itrelates-to-investment-management-business/ (accessed 15 August 2012).

29. Mutezo, A. T. (2005). Obstacles in the access to SMME finance: an empirical perspective on Tshwane. University of South Africa.

30. NFIB. (2012). Small business, credit access, and a lingering recession. Retrieved from http://www.nfib.com/Portals/0/PDF/AllUsers/research/studies/small-business-credit-study-nfib-2012.pdf

31. Nieman, G., and Neuwenhuizen, C. (2009). Entrepreneurship: A South African Perspective. Pretoria: Van Schaik.

32. Nieuwenhuizen, C., and Groenewald, D. (2004). Key issues for improvement of entrepreneurial activity in South Africa: Unisa. SAIMS Conference.

33. Office of Advocacy. (2014). Frequently asked questions about small business finance. Retrieved from https://www.sba.gov/sites/default/files/Finance-FAQ-2016_WEB.pdf

34. Osuala, E. C. (2009). Business and computer Education. Enugu: Cheston Agency Ltd.

35. Ragin, C. C. (2012). How many qualitative interviews is enough? Expert voices and early career reflections on sampling and cases in qualitative research. National Centre for Research Methods. Retrieved from http://eprints.ncrm.ac.uk/2273/4/how_many_interviews.pdf

36. Rajaram, R. (2008). A needs analysis of financial management and accounting skills in the SME sector in KwaZulu-Natal. In fulfilment of the requirements of the degree of Master of Commerce School of Management. University of KwaZulu-Natal.

37. Robu, M. (2013). The Dynamics and Importance of SMEs in Economy. The USV annals of economics and public administration, 13(1), 84-89.

38. SAICA. (2010). To audit or not to audit? Retrieved from https://www.saica.co.za/tabid/695/itemid /2405/language/en-ZA/To-audit-or-not-to-audit.aspx

39. Sian, S., and Robert, C. (2009). UK small owner-managed businesses: accounting and financial reporting needs. Journal of Small Business and Enterprise Development, 16(2), 289-385.

40. South Africa. (2008). Companies Act 2008: Act. Pretoria: Government Press.

41. The Business Place. (2009). Fact Sheet. University of Stellenbosch. Retrieved from http://www.reciprocity.co.za/documents/Reciprocity_BoPFactSheet_BusinessPlace.pdf

42. Turton, N., and Herrington, M. (2012). Global Entrepreneurship Monitor: South Africa. Retrieved from http://www.gsb.uct.ac.za/files/2012GEMSouthAfricaReport.pdf

43. Turner, M. A., Varghese, R., and Walker, P. (2008). Information Sharing and SMME Financing in South Africa: A Survey of the Landscape. PERC Press. North Carolina. USA.

44. Warren, C. A. B. (2002). Qualitative Interviewing. In J.F. Gubrium and J.A. Holstein (eds.), Handbook of Interview Research: Context and Method. Thousand Oaks, CA: Sage.

45. Wiersch, A. M., and Shane, S. (2013). Why small business lending isn't what it used to be. Economic Commentary, 10. Retrieved from http://econpapers.repec.org/article/fipfedcec/y_3a2013_3ai_3aaug14_3an_3a2013-10.htm

46. Wignaraja, G., and Jinjarak, Y. (2015). Why do SMEs not borrow more from banks? Evidence from the People's Republic of China and Southeast Asia (ADBI Working Paper No. 509). Retrieved from https://www.econstor.eu/bitstream/10419/115330/1/815332033.pdf 